\title{
Diversity: Negotiating difference in Christian communities
}

\begin{tabular}{|c|c|}
\hline \multicolumn{2}{|c|}{$\begin{array}{l}\text { Authors: } \\
\text { Marilyn Naidoo }{ }^{1} \\
\text { Stephan de } \text { Beer }^{2,3}\end{array}$} \\
\hline \multicolumn{2}{|c|}{$\begin{array}{l}\text { Affiliations: } \\
{ }^{1} \text { Department of Philosophy, } \\
\text { Systematic and Practical } \\
\text { Theology, University of } \\
\text { South Africa, South Africa }\end{array}$} \\
\hline \multicolumn{2}{|c|}{$\begin{array}{l}{ }^{2} \text { Centre for Contextual } \\
\text { Ministry, Faculty of Theology, } \\
\text { University of Pretoria, } \\
\text { South Africa }\end{array}$} \\
\hline \multicolumn{2}{|c|}{$\begin{array}{l}{ }^{3} \text { Department of Practical } \\
\text { Theology, Faculty of } \\
\text { Theology, University of } \\
\text { Pretoria, South Africa }\end{array}$} \\
\hline \multicolumn{2}{|c|}{$\begin{array}{l}\text { Project leader: S.F. de Beer } \\
\text { Project number: } 86233689\end{array}$} \\
\hline \multicolumn{2}{|c|}{$\begin{array}{l}\text { Description: } \\
\text { This research is part of the } \\
\text { research project, 'Social } \\
\text { Justice and Reconciliation', } \\
\text { which is directed by Dr } \\
\text { Stephan de Beer, Director of } \\
\text { the Centre for Contextual } \\
\text { Ministry and member of the } \\
\text { Department of Practical } \\
\text { Theology, Faculty of Theology, } \\
\text { University of Pretoria. }\end{array}$} \\
\hline \multicolumn{2}{|c|}{$\begin{array}{l}\text { Corresponding author: } \\
\text { Marilyn Naidoo, } \\
\text { naidom2@unisa.ac.za }\end{array}$} \\
\hline \multicolumn{2}{|c|}{$\begin{array}{l}\text { Received: } 03 \text { June } 2016 \\
\text { Accepted: } 19 \text { July } 2016 \\
\text { Published: } 01 \text { Dec. } 2016\end{array}$} \\
\hline \multicolumn{2}{|c|}{$\begin{array}{l}\text { How to cite this article: } \\
\text { Naidoo, M. \& De Beer, S., } \\
\text { 2016, 'Diversity: Negotiating } \\
\text { difference in Christian } \\
\text { communities', HTS Teologiese } \\
\text { Studies/Theological Studies } \\
\text { 72(1), a3525. http://dx.doi. } \\
\text { org/10.4102/hts.v72i1.3525 }\end{array}$} \\
\hline \multicolumn{2}{|c|}{$\begin{array}{l}\text { Copyright: } \\
\text { (c) 2016. The Authors. } \\
\text { Licensee: AOSIS. This work } \\
\text { is licensed under the } \\
\text { Creative Commons } \\
\text { Attribution License. }\end{array}$} \\
\hline \multicolumn{2}{|l|}{ Read online: } \\
\hline 口fist: & $\begin{array}{l}\text { Scan this } Q R \\
\text { code with your } \\
\text { smart phone or } \\
\text { mobile device } \\
\text { to read online. }\end{array}$ \\
\hline
\end{tabular}

This article seeks to present challenges of negotiating difference and diversity in Christian communities in South Africa today. It reflects the intersectional nature of racial, gender, ethnic and economic difference, and ways in which land, capital and other power constructs continue to underpin and deepen exclusion. It then considers the status of diversity in Christian communities highlighting ways in which the fault lines in society are running through Christian communities, and how such communities almost spontaneously engage in 'othering' more naturally than in 'embracing'. The article proposes the re-conceptualisation of diversity within the bigger South African project of socio-economic transformation, and that the conversation about difference and diversity in Christian communities should be brought into dialogue with critical diversity theory, which considers diversity in relation to equity, human rights and social justice. Finally, the article provides an overview of the contributions that form part of this collection of articles, tracing how a number of Christian communities seek to negotiate diversity and difference ecclesially and theologically.

\section{Introduction}

South African society is a long way from reflecting a 'normal' society, as deep social divisions continue and the diversity of the population remains largely untapped as a resource; more often than not it is regarded as a source of difficulty (Booysen et al. 2007:1). The internalisation of apartheid stereotypes, structures and beliefs has resulted in degrees of resistance, rigidity and low levels of adaptability of the individual or groups to the changing South African environment and emerging new or shifting value systems. Jansen (2009:5) calls this 'bitter knowledge': it represents 'how students remember and enact the past'. This is a product of intergenerational transmission of spoken and unspoken messages from parents, the church, school, cultural associations and the peer group (2009:5). These messages have not been interrupted over the period of transition despite the major changes in the formal institutions of democracy. They take place in a context where racism is still fresh and where the legacy of apartheid is visible in concrete form in the shape of persistent racial inequality and segregation.

\section{The changing South African scene}

In different communities across South Africa, diversity in terms of race, ethnicity, nationality, gender, sexuality, class, generation and religion, presents itself as a challenge to religious communities, schools and institutions of higher education, residential complexes, businesses, sporting clubs, and every other entity alike. Instead of hospitable embrace and warm inclusion or deep forms of belonging and intimacy, we are increasingly witnessing withdrawal and separation, re-segregation, animosity and, more recently, blatant verbal and even physical attacks on each other.

More than 20 years after the formal collapse of apartheid, January 2016 started off for South Africans with a fresh outburst of racist and racially laden remarks on social media, instantly tearing off the plaster that had been so carefully applied to hide the wound festering for so long. Sadives (2016) suggests that racism is on the increase, if just considering the number of complaints of racism that are registered per month with the South African Human Rights Commission (SAHRC).

Racial difference, the on-going 'othering' of people based on pigmentation, the inability to embrace our common humanity as a point of departure, the reality of on-going racialised and segregated socialisation and new emergent forms of re-segregation, all deny our commonness and emphasise our difference. Racial categories are now used to identify and employ suitable candidates for jobs, employed as a means for redressing past injustices, but at the same time reinforcing our racialised pasts and constructions of identity (cf. James 2012). 
Penny Sparrow speaks of the largely black crowds on Durban beaches over the Christmas holiday period as 'monkeys' (cf. Wicks 2016) and students at the Wits University proudly wear T-shirts on which it is written ' $\mathrm{f}$ *ck white people' (Nhlapo 2016; Genever 2016). Race, and race-based prejudice or anger or pain, differently construed and interpreted, indeed still matters, and despite new evidence to the contrary - of mixed schools, mixed relationships and marriages, and mixed neighbourhoods - race still too often tears us apart. At the same time, the deep structural forms of racism that defined, among others, our corporate, educational and religious institutions for decades and more have not suddenly appeared overnight without any traces of it still existing, either subtly or more pervasively, in ways that deal exclusion and hurt (De Vos 2013).

Ethnic difference has long been an organising principle for conflict and war in many parts of the world. Through apartheid, urban townships in South Africa have not just been racially segregated but also ethnically divided. A place such as Soshanguve in the north of Pretoria is named after the different ethno-linguistic groups residing in the area Sotho, Shangaan, Nguni and Venda - who were ethnically segregated at the birth of this township. And although the different regions in Soshanguve are today much more fluid ethnically, and also exhibiting concentrations of Africans from beyond South Africa's borders, some of the same ethnic segregations still continue to exist.

In 2008, and then sporadically thereafter, a wave of xenophobic attacks hit communities all over South Africa. People of colour from across South Africa's borders - Somalis, Zimbabweans, Mozambicans, Pakistanis and others - were targeted, businesses looted, shops burnt down, and in some instances people even got killed (cf. Crush 2008:11, 56). Even local Shangaan people, mistaken for being citizens of other countries, were targeted. Ironically and sadly, only people of colour suffered this fate, unlike their white European counterparts. Some commentators argue that ethnicity, and ethnocentricity is, unfortunately, surfacing afresh in local South African politics. James (2012) speaks of Mbeki's 'African nationalism' and Zuma's 'ethnic social Darwinism' as symptoms of such a shift towards ethnic or ethnocentric politics.

Issues of land also cause ethnic differences to surface. The Khoisan made submissions to the Human Rights Commission calling for reparations from the British and Dutch governments for the roles they played to dispossess the Khoisan of their land (cf. Child 2015). Their Gauteng chairman, John Rooyen, argued that the Khoisan were the first people to be met by European colonists, prior to meeting the Xhosa or other ethnic South African groups. Similarly, the Griqua royal house was also preparing a land claim deeply dissatisfied with how they were excluded from land reforms (cf. Child 2015). A Khoisan woman, for example, challenged politician Julius Malema, who is very vocal about land reforms and land reclamation (cf. Quintal 2016). She told Malema that he had no authority to talk about land as the
Khoisan was the only authoritative voice in this regard, having been dispossessed 360 years ago:

We were the first people of this nation. We were the first people of southern Africa and we still face oppression ...

We lived here and you, your ancestors, and the white ancestors found us here. Only we can talk about land ownership. (n.p.)

Much work has been done on gender in South Africa since 1994. And yet, the struggle for equality continues, as children are still socialised into stereotypical gender roles from preschool. Gender inequality still exists in many work places and the brunt of the burden in families, particularly those in poor communities, is unequally carried by women (Rogan 2014). Gender studies concern itself not only with the issues of women, but increasingly also with masculinities (cf. Elliott 2003; Redpath et al. 2008; Gennrich 2013), the challenges faced by the LGBTI (Lesbian, Gay, Bisexual, Transgender and Intersex) community, and the intersectional challenges when simultaneously facing multiple oppressions, such as the experiences of a black lesbian woman having to contend with prejudices of both race and sexuality.

LGBTI persons have become more visible in all communities but fight an uphill battle for affirmed dignity and full acceptance. Seoketsi Moeketsi is a black queer trans-woman at the University of the Free State. She speaks of her difficult, even 'suffocating' journey as a student of this University, not only having to deal with institutional racism but also with issues of patriarchy and transphobia (Pilane 2016). She says, 'I cannot breathe in this university' (Pilane 2016), having to fight the prejudice of both management and fellow students, in everything from how she is addressed in class, to which toilets she can safely use. Not only do people experience prejudice in the form of subtle, overt or institutional exclusions, but also in the form of physical violence, even death. Sosin (2014) writes about the violence against LGBTI people in the Thokoza township east of Johannesburg. Between 2011 and 2014 three people were killed for their openly gay or lesbian orientations. In addition, reports of so-called 'corrective rapes', and probably countless unreported cases, demonstrate the vicious and violent prejudice against people of sexual orientations different from what mainstream society views as 'appropriate'. 'Corrective rape' is the term used to describe the phenomenon of raping people in order to 'convert' them to heterosexuality, or to 'cure' them from what is deemed pathological (Sosin 2014; cf also Alagia n.d.; Hames 2011:87-91). Hames (2011:87-91) strongly challenges the very use of this term to describe rape motivated by hatefulness towards, in this case, mostly black lesbians. She argues that the very term contributes to an internalisation of the very oppression people fight against, using 'positive' language for what is an evil act.

Van Vollenhoven and Els (2013) speak about the ways in which the school system in South Africa prejudices LGBTI learners, either overtly or through what they call a 'hidden curriculum':

Silence, misconceptions, disregard and social prejudice produce a 'hidden curriculum' in the education system that violates 
LGBT students' rights to dignity and equality, and forms a paradox against the Constitutional value system that underpins our country and its democracy. External factors, such as the community and religious sentiment regularly infiltrate the education system on all levels and send out the message that it is fine to be homophobic and it is wrong to be different than the majority. This indicates that although all students have the same human rights, the way society and schools implement these rights, is a violation of the right not to be discriminated against on the basis of sexual orientation. (p. 281; cf. also Harber \& Serf 2006:966-997)

Mbembe (2013:n.p.) speaks of 'the shift from a society of control to a society of consumption' post-1994, but then also not consumption without new forms of control, commenting on how the post-apartheid state protects the market with force. This is echoed in the work of Terreblanche $(2012,2012 b$, 2015), describing the history of inequality in South Africa, but specifically articulating how political processes since 1986 contributed to further intensify socio-economic inequality instead of reducing it.

While on the one hand the concentration of capital is proportionally still in the hands of white South Africans, an emerging black middle class and small black elite contribute to an intensifying class divide between those with access to opportunity and wealth and those without. Mbembe (2013) speaks of the majority of 'propertyless citizens' and a small minority who own properties, can pay taxes, and protect themselves and their resources through 'privately armed men' and private security forces, ensuring a citizenry divided along economic and class lines. Mbembe (2013) goes as far as questioning whether our society, increasingly an armed society, could be conceived of as a democracy at all:

an armed society is anything but a polite - a civil - society. It is not a political community. It is hardly a democracy. (n.p.)

This is evident in party political formations, in different student formations actively involved in recent protest actions on campuses around South Africa, in the re-segregation of neighbourhoods with some of the most and only integrated neighbourhoods being gated communities behind heavily securitised walls and fences. It is perhaps also true, in a general sense, of the Christian faith community in South Africa.

\section{Diversity and Christian communities}

Because our racialised society often both produces and reflects hostility, unequal treatment, misunderstanding, conflict, violence, compromised life opportunities and other social ills, our nation is searching ways to overcome 'race'. Race is a significant concept in relation to other issues of diversity. Soudien (2010:352) states that 'race' represents 'the generative mechanism through which other forms of difference are constituted, reconstituted, reinforced or gain expression'. He further states that racism is often intertwined with other forms of discrimination based on social class, gender, ethnicity, religion, language, sexual orientation, and xenophobia and uses these to justify and reproduce itself (Soudien 2010:358).
Many believe religion is a potential force for overcoming the racialised society and nearly all religions have spoken out against inequality. Since religious organisations are 'mediating institutions between the private and public spheres' (Smith, Stones, Peck \& Naidoo 2007), they have the potential to draw people out of their private, racially segregated lives, into a social space where human interactions are more intimate than in the public arena. If anyone should be doing something about our racialised society, they say, it is the Christians, as their religion calls for it and their faith gives them the tools and the moral forces needed for change (Christerson, Edwards \& Emerson 2005). The new interracial relationships that are created in these religious organisations can become a model of social cohesion for South African society in the future. Social cohesion is understood as a state of affairs concerning how well people in a society 'cohere' or 'stick' to each other, but this occurs only if they can trust, help and cooperate with their fellow members of society and if they share a common identity or a sense of belonging to their society (Chan, To \& Chan 2006:274).

Social cohesion as a normative category is far from unproblematic though. Various scholarly voices engage the notion of social cohesion very critically, considering it as social co-option by the dominant cultural expression or religious group or gender, in uncritical ways, thereby continuously perpetuating inequalities instead of fostering social justice (Bernard 1999; Lister 2000; Fitzpatrick \& Jones 2005; De Beer 2014). In various contributions in this collection of articles authors position diversity discourses within a justice conversation, arguing that the uncritical promotion and embrace of diversity, without considering the reproduction of inequality or the co-option of excluded voices or narratives by dominant discourses, are extremely problematic.

The way diversity, especially race, gender and sexuality has been approached by Christian communities has not always been productive in bringing about dialogue about the topic. The reality in far too many cases is that 'churches, the presumed agents of reconciliation, are at best impotent and at worst accomplices in strife' (Volf 1996:36). Church congregations should be, by definition, places of acceptance and love, but are also (an) arenas for subtle racial tension. The biggest challenge perhaps is the fact that churches largely reflect the social divisions of our society (Van Rooi 2010). And even when they reflect greater diversity, there is the real risk of embracing an uncritical kind of cohesion without deconstructing dominant constructs that continue to perpetuate inequality or injustice. Part of the problem is that healing and reconciliation have not been sufficiently internalised or explicated in order to be sustainable. The annual South African Reconciliation Barometer (2015), which is a nation-wide survey measuring reconciliation on an annual basis, reveals that, although race relations in South Africa have improved, interracial interaction and socialisation remains low. It was reported that a majority of respondents (61.4\%) feel that race relations since 1994 have either stayed the same or deteriorated. The same is most likely to be found in church communities. 
At the same time, the Christian community is indeed no homogenous community and, therefore, all the fault lines of society also express themselves in the Christian community. Christian communities are not immune against constructs and practices that often engage much more spontaneously in 'othering' than in 'embracing'. Diversity is then seen as something to be managed instead of a gift to be celebrated.

Recent protests on university campuses in South Africa underscored this reality. Students belonging to very different political parties, and non-partisan students, might all belong to the same local church. Some might engage actively in protests for policy changes around fees, outsourcing of workers or language. Others might actively oppose the envisaged changes their peers protest for. Still others might engage in prayer activities for peace and reconciliation, and maybe sometimes for justice, but at other times also praying against the protestors. A large majority of Christians might be silent bystanders, apathetic towards the issues at stake. Mosa Moerane's inner tension on these matters is revealing (see Pilane 2016):

Second-year law student Mosa Moerane is caught between protest and prayer. She is a devout Christian and a black student who believes that the transformation project at the university is nonexistent and was abandoned by university authorities before it even began.

She finds the approach of Christian Revival Church's (CRC) to be a silencing tactic that erases her intersecting identities. 'I am still black on Sunday, I still cannot afford fees when I am praying in church. I have never thought of choosing my blackness over my faith, but today I was forced to' says Moerane. (p. 4)

\section{Worshipping communities}

The larger Christian community has members representing all the different faces of our diversity. And yet, local embodiments of the Christian community often display stark characteristics of socio-cultural exclusivity, being isles of homogeneity in the face of the extremely diverse contexts surrounding them. This is true of urban, suburban, rural and township churches.

Inner city churches were often the first to deal with neighbourhood changes in the post-apartheid 1990s, and in order to simply survive, had to negotiate difference, which was done in different ways and to varying degrees of 'success'. The different ways of dealing with diversity in post-apartheid inner city congregations also resulted in different outcomes, which is a question for more intentional research and reflection by itself.

Township and suburban churches have by and large remained the same in terms of racial or ethnic homogeneity, with some exceptions in traditionally English-speaking suburban congregations. However, although the first wave of demographic changes mostly affected inner city and surrounding neighbourhoods, often causing significant congregational change, challenge and even closure, the next wave of demographic changes is still taking place affecting many suburban neighbourhoods.
There are also examples of churches that have changed from predominantly white to predominantly black in ways that do not characterise 'transformation' but rather the re-segregation of the church as the new dominant ethnic or vernacular group determines, even dictates the 'new culture' of the congregation, once again becoming exclusivist in nature.

Charismatic mega churches often tend to be the only congregations displaying significant racial, and to lesser degrees, economic diversity. Whether their relative success in this regard, in comparison to traditional mainline churches, could only be ascribed to their more vibrant and popular styles of worship, or perhaps also their commitment to make public transport available to potential members from diverse and often economically disadvantaged locations, need to be investigated.

There are also new expressions of Christian community, ranging from the establishment of intentional communities seeking to be in solidarity with the poor or to demonstrate racial, cultural or economic inclusivity, to the creation of faith-based (non-profit) organisations committed to social change. Sometimes these new communities are able to deal with diversity more progressively and creatively than more traditional Christian communities, often because of their intentionality to be(come) households of hospitality. However, not all new expressions of Christian community succeed at this. With regard to migrants, Hay (2014:31) says the church is the site of transnational and local networks which many migrants draw on for social and spiritual capital and to negotiate belonging in a frequently hostile environment'. The church therefore functions for migrants as a site for negotiating and constructing identity, belonging and agency, both locally and trans-nationally.

\section{Practices and polity}

One area in which much debate, conflict and also hurt are experienced, is in the area of gender discrimination or sexism, which legitimises unequal relations of power between men and women (oppressive patriarchal relations that relegate women to subservient lower status), and which opposes female ordination. This is not to down play the significance of the ideological manipulation of other forms of difference. Homosexuals are welcomed in the faith community and regarded as devoted Christians, but church councils are officially allowed to exclude homosexuals who are honest about their sexual lifestyle (Dreyer 2008:1236). Debates range from the ways in which the Dutch Reformed Church first accepted at its General Synod, with an overwhelming majority, the principle of same-sex marriages, to a reversal of that decision days later. It includes legal battles to the level of the Constitutional Court to determine whether the Methodist Church is in its rights not to accept as a minister of the church someone who has entered into a same-sex union with her partner, but also the work of Inclusive Ministries, a faithbased NGO supporting local congregations to deal with issues related to LGBTI persons. 
At the same time the point needs to be made that gender is not just about women and sexuality, and is not just about gay and lesbian people, though they are often the ones who highlight the issues precisely because they have been defined as not the norm. Here we see that categorisation tends to homogenise groups and create a discursive illusion that members of a category share more in common than they in fact do. This hides the variety of interests, social positions and identities ascribed to the group by that category (Cross \& Naidoo 2012). It must be noted that individuals have multiple identities and these identities must be understood as they intersect with each other. Simplifying the complexity of experience makes it difficult if not impossible to account for the nature of the intersections of race, class, gender and other forms of difference and these intersections have yet to be explored and theorised (Cross \& Naidoo 2012:231).

\section{The challenge of diversity}

Diversity has been traditionally associated with race, gender, ethnicity and class, as seen above. Recent literature on diversity has widened the scope of diversity to embrace various characteristics such as age and physical traits, sexual orientation, ethnic and religious background, socioeconomic status, birthplace and hometown, social and political affiliations, seniority and experience, education and training, and so forth. As such, diversity represents a mix of characteristics that makes each person or group unique (Goduka 1996:30). As diversity involves a state or fact of being diverse or different to a variety of opinions, the important point in the definition is that it indicates that there is a point of difference, which is socially constructed (Cross \& Naidoo 2012). The boundaries between different categories of social groups and knowledge are a function of power relations as 'power relations create boundaries, legitimize boundaries, reproduce boundaries between different categories of groups, gender, class, race, different categories of discourse, different categories of agents' (Bernstein 2000:5).

Conceptualisations of diversity range from tolerance of difference, 'affirmation' or 'celebration' of diversity, to diversity as a strategy for embracing, or accommodating or engaging differences (Goduka 1996). Cross states that 'conceptualisations of diversity generally converge on or point to the need for integrating the politics of cultural and identity recognition with the politics of social justice and equity', which represents a key strength in South African diversity discourse (Cross 2004).

Diversity as a civic value involves new social competences and practices, and developing capacities for 'engaging difference' is essential to the success of a diverse democracy. A commitment to diversity is manifested in the Constitution with the broad aim to create and nurture a non-racial, nonsexist, non-discriminatory society where all people can recognise each others' differences, while at the same time live in peace and harmony. Schneider (1997:128) suggests that developing capacities for 'engaging difference' is essential to the success of a diverse democracy.

Given the legacies of apartheid, South African scholars also face the challenge of developing a critical theory of diversity that takes seriously issues of equity, human rights and social justice (Cross 2004). This requires a re-conceptualisation of diversity in the context of the on-going social and institutional transformation in the country. Critical diversity theory acknowledges 'the centuries of colonial history and ideologies of Western/European (white) superiority and African or Asian (black) inferiority' (Steyn 2011:18). Such an orientation enables a radical look at constructions of difference that underpin institutional culture and interpersonal interactions, and moves beyond merely tolerating or assimilating differences into dominant practices, which is the case for some approaches to diversity (Steyn 2011:19).

Diversity is seen as belonging to a peripheral domain of values and behavioural concerns. To draw on West's (1994:20) analysis of culture, there is 'no understanding of the "structural character" of diversity as rooted in institutions such as families, schools, churches and mass media, etcetera'. This means that diversity has only received significant attention in those institutions where there has been strong institutional leadership and commitment at the management level (Cross 2004). This then begs the question of how Christian communities respond to difference with a plethora of differing theological positions and practices and where diversity issues are contested as they are attached to religious dogma. In dealing with 'otherness', Christians cannot agree whether the goal is to 'understand' or to 'convert' or to bring them 'into the fold' or to explore the 'interconnectedness' (Foster 2002:21). How then do we negotiate difference in religious communities? Are churches that are structured in patriarchal and hierarchical ways with their concomitant authoritarianism and power truly open to difference? How to deal with the reality of interlocking systems of oppression within religious communities and the resistance to change?

It would seem that there must be engagement in discourse on difference to make visible the hidden power dynamics that produce oppression, subjugation and domination based on a politics of identity or difference (Giroux 2003:84). The religious culture is not limited to religious beliefs, communal rituals or shared traditions. On the contrary, it begins with the way that such 'manifest phenomena are produced through systems of meaning, through structures of power and through the institutions that are deployed' (Donald \& Ranttansi 1992:4). What matters is to identify the structures of power, the ecclesial rituals and social practices that produce discriminatory outcomes. This involves an analytic skill to unpack how these systems of oppression in the church intersect, co-construct and constitute each other (Steyn 2011:20). Gilligan (2002) states that learning how diverse constituencies use power to control and shape the agenda of the church and its mission is critical. 
A significant part of the challenge in exploring diversity has been the insistence on the abstract, the general and universal in the name of Christianity, which all too often has amounted to the eradication of difference in the interest of hegemony of the dominant (Christerson et al. 2005). What is evident is a pecking order of systems and sources of knowledge, with the white, patriarchal and Western perspective at the top of the pyramid that is consistently supported in understated ways as universal. This universalism is highlighted by Buell and Johnson Hodge (2004:251) who state that 'the familiar idea that Christian identity renders ethno-racial differences irrelevant provides a problematic loophole for white scholars to deny or overlook the saliency of race'. And even though white scholars are now engaging in critical race theory and other theoretical frameworks; unfortunately, as long as the early Christian world is organised primarily in ethnic categories of 'Jew', 'Greek', 'Gentile', and so forth, there is no synthetic way to move beyond the 'rhetoric of race and ethnicity' that acknowledges ethnic diversity in the ancient world (Byron 2012:109). Here it is important to determine how and to what extent the use of the Bible and a critical reading thereof, complete with its ambiguity in matters of identity-promotion (Punt 2009), can become a useful ally in contemporary racialised discourse and the perpetuation of racial identities. The work of uncovering dominant, universal, Western paradigms of knowledge will involve 'bringing to the foreground other epistemologies, other principles of knowledge and understanding and consequently, other politics, other ethics' (Andraos 2012:7). The point of highlighting difference then is to highlight the implicit values and norms that need to be thoroughly articulated, analysed, evaluated, deconstructed and reconstituted. It would also involve understanding the underlying theological criteria whether it is from religious discourse or dogma, rituals or ecclesial traditions that is brought to assumptions and conceptualisations.

The idea for this special edition is from a recent symposium on 'Diversity: Negotiating difference in the Christian communities' held at the University of South Africa in March 2016. Speakers were asked to focus on case studies of difference in Christian communities to look at the ways in which difference is constructed, how it is operationalised in Christian communities, how its significance shifts and most critically why difference continues to matter. While studies in diversity within the broader South African context have been examined extensively by scholars, we have identified a gap in the literature that specifically deals with faith and diversity. A dearth of literature and research exists to help Christians and communities with a response to diversity, and to link their diversity efforts with a theological understanding in creating inclusive communities. Consequently, the intent of editing this issue is to highlight literature and research that deal specifically with the issue of faith, diversity and social justice within Christian communities.

Each article makes a contribution by presenting a case study of a different aspect of diversity and by outlining how this difference is negotiated either from the standpoint of local congregations, theological education, faith-based organisations addressing societal challenges, or the broader Christian community. The intention of exploring intersections of the diversity imperative is to pose several essential questions to which scholars and Christian leaders might respond.

To begin with, McEwen and Steyn focus their conceptual article on Critical Diversity Literacy (cf. Steyn 2011:15-42) by considering diversity, difference, and otherness from the perspective of contemporary religious communities and contexts. They argue that these religious sites are important elements of the broader project of instilling non-racialism and non-sexism into society, but it has been largely overlooked within existing literature. They also highlight the relationship between whiteness and Christianity in the context of postapartheid South Africa as a contested transformational space.

Naidoo presents an ethnographic study on managing diversity via the institutional culture of two Protestant theological colleges in South Africa to understand how these interactions of dealing with diversity formed and prepared future religious leaders. Her findings suggest a colour-blind theology in one institution perpetuating surface change to a lack of structural alignment of diversity initiatives to make a meaningful difference in the second institution. This study highlights the lack of awareness of the way in which institutions are organised, which then holds direct consequences for students, identity and transformation.

Dube addresses the issue of masculinism by analysing the Mighty Men Conference in South Africa as a case study. He makes a comparison between Promise Keepers in America (PKA) and the Mighty Men Conference (MMC) in South Africa. The article investigates the specific ways in which PKA and MMC are ideologically similar, while also evaluating how their differences accrue dissimilar results with respect to their missions on race reconciliation. $\mathrm{He}$ suggests that the absence of race discourse in the MMC is especially problematic given the visibility of race in public discourse in South Africa in general, and also points to a masked refusal by certain groups of white men to give up white male privilege in the post-apartheid public sphere.

West, Van der Walt and Kaoma explore developments in sexuality by reflecting on the work that has been done over the past decade between African LGBTIQ (Lesbian, Gay, Bisexual, Trans, Intersex, Queer) Christians, African theological educators and African church leadership. They argue that for sexuality to become the subject of the doing of theology, particular marginalised sexual communities, like the LGBTI community, with their own particular experience, must become the primary dialogue partners in the doing of theology.

Hankela extends the discussion of the politics of ethnicity in the context of mainline churches in South Africa from results of ethnographic fieldwork conducted in a Methodist Church in Johannesburg. She reminds us that the category of ethnicity is largely missing in the critical theological interrogation of diversity which could facilitate the building of inclusive 
worship spaces, whereas neglecting it means neglecting a dynamics that impacts on the every (Sun)day life of ordinary churchgoers.

Hadebe presents an interesting case study of the challenge to male power, privilege and leadership in the Catholic Church through an intervention of Catholic Women Speak (CWS) at the Synod of Bishops on the Family in October 2015. This exercise of power to the exclusion of women's voices was challenged by CWS. She presents a 'reading' of the social script of injustice and differential power relations which militate against diversity conscientisation that leads to justice orientated actions.

De Beer considers the journeys of an inner city faith community in Pretoria. In his article he is exploring whether an emphasis on the management of diversity, which is widespread in organisational and ecclesial practices and languages, should not be replaced with a spirituality of vulnerable embrace, as he finds it in this specific faith community. He brings their invitation and rather radical embrace of diversity and dance with chaos, with a posture of vulnerability and a vision of justice, in conversation with literature on chaordic organisations and chaordic leadership. He then suggests that their emphasis on embrace instead of management, opening up the possibility of retrieving and affirming the hidden beauties and potentialities mediated by diversity, is to practise 'chaordic beauty'.

And finally Finn attends to sexuality and gender diversity in asking the question whether we can 'love the sinner, not the sin?' He argues that an African queer theology is necessary given the increasingly urgent calls for transformation of religious spaces so as to be more inclusive of sexually diverse congregants. He writes of the many approaches available to faith communities as a way to advocate for inclusion, like reclaiming the Bible or developing alternative discourses that challenge the hetero-patriarchy of the Bible to sexual and gender diversity awareness for theological training. He motivates for the development of the theological capacity of queer communities in terms of biblical, theological and interpretative resistance.

The theological term of imago dei (image of God) emphasises that all people are created in God's image and are worthy of respect. If our starting point is difference, it becomes a matter to be negotiated and managed, and often merely tolerated. An unsophisticated theology of tolerance is adequate for superficial engagement but not for sustained and meaningful action (McNeil \& Pozzi 2007). However, if our starting point is our common humanity, it represents a remarkable shift in approach, both theologically but also practically in how we engage diversity, difference or 'the other'. Honouring diversity recognises our interconnectedness and brokenness. It reflects the multiple conflicts and commitments that emerge as Christian communities bound by time and place seek to be faithful to the presence of the Christ in their lives. The theological import of this edition is that it proposes a different way of being human. The way of being human is predicated on the mystery of the encounter of self and the other. But unlike many such claims for an I/thou relationship or of coming 'face to face' with the reality of another human being, what is asserted here is that the human encounter is always in a concrete social location and that the encounter has a purpose, namely social and personal transformation. The significance of gender, race, ethnicity or nationality to name a few parameters of concrete human life has only been studied with the advent of liberation theologies, in defining what it means to be human. As Thislethwaite and Cairns (1994:10) suggest, we need to develop a theological anthropology that takes account of differences in concrete social locations for the transaction of becoming human in the process of transforming the world.

Many Christians believe that the valuing of difference has been a part of Christian theology since the beginning of time, though Christians have not always followed through on actions. Perhaps the poor follow through is the result of a desire for stability and a collective aversion to disruption (Jun \& De la Rosa 2013:3). Perhaps as Daryl Smith (2009) submits, 'we are happy to appreciate and celebrate diversity of individuals and groups as long as, at the institutional level, things remain neutral'.

Our context requires a new vision of the social whole in the light of our painful history and recurring existential suffering of past and current experiences. Structural inequalities in society continue to make discussions of colour blindness much more problematic. What are the benefits of promoting increased engagement with diversity in Christian communities, at the risk of being less comfortable and more embracing of tensions that arise with significant personal and institutional change? What about those who have benefited from or have been harmed by the existing arrangements of power? Is there space to verbalise the unsaid or the unsayable in communities?

There are a myriad of complex interlocking issues that need to be taken into account to engage diversity in a successful and a meaningful way. Woodley states (2001:17): 'we need a plethora of perspectives and cultural worldviews if we are to see a clearer picture of the immense grandeur of our creator God'. It is at this point we argue that the discourse must evolve and provide deeper and more complex reasons as to why we ought to incorporate change into practices of justice that contribute to institutional vitality and viability. This special issue serves as a call to accept a vision of the world that does not devalue difference or identity but rather embraces it and places it in celebration with others.

\section{Acknowledgements Competing interests}

The authors declare that they have no financial or personal relationships which may have inappropriately influenced them in writing this article. 


\section{Authors' contributions}

M.N. provided the conceptual grounding and S.d.B. provided the contextual background.

\section{References}

Alagia, F., n.d, 'Corrective rape: The unbearable suffering of South African lesbian women', viewed 25 February 2015, from http://www.capechameleon.co.za/ printed-issue/issue-10/news-arena2/

Andraos, M.E., 2012, 'Engaging diversity in teaching religion and theology: An intercultural, de-colonial epistemic perspective', Teaching Theology and Religion 15(1), 3-15.

Bernard, P., 1999, 'Social cohesion: A critique', CPRN Discussion paper no F09, Canadian Policy Research Networks, Ottawa.

Bernstein, B.B., 2000, Pedagogy, symbolic control, and identity: Theory, research, critique, Rowman \& Littlefield, London.

Booysen, L., Kelly C., Nkomo M.S. \& Steyn, M., 2007, 'Rethinking the diversity paradigm: South Africa practices', International Journal of Diversity in Organizations, Communities and Nations 7(4), 1-10.

Buell, D.K. \& Johnson Hodge, C., 2004, 'The politics of interpretation: The rhetoric of race and ethnicity in Paul', Journal of Biblical Literature 123, 235-251.

Byron, G.L., 2012, 'Race, ethnicity and the Bible: Pedagogical challenges and curricular opportunities', Teaching Theology and Religion 15(2), 105-124.

Chan, J., To, H. \& Chan, E., 2006, 'Reconsidering social cohesion: Developing a definition and analytical framework for empirical research', Social Indicators Research 75, 273-302.

Child, K., 2015, 'Khoisan: It's our land and we want it back', posted on 26 November 2015 viewed 15 March 2016, from http://www.timeslive.co.za/thetimes/2015/11/26/ Khoisan-Its-our-land-and-we-want-it-back

Christerson, B., Edwards, K.L. \& Emerson, M.O., 2005, Against all odds: The struggle for racial integration in religious organizations, New York University Press, New York.

Cross, M., 2004, 'Institutionalising campus diversity in South Africa higher education Review of diversity scholarship and diversity education', Higher Education 47, 387-410.

Cross, M. \& Naidoo, D., 2012, 'Race, diversity pedagogy: Mediated learning experience for transforming racist habitus and predispositions', Review of Education, Pedagogy, and Cultural Studies 34(5), 227-244.

Crush, J, 2008, 'South Africa: Policy in the face of xenophobia', Migration Information Source: country profiles, viewed 7 March 2016, from http://www. migrationinformation.org/Feature/display.cfm?ID $=689$

De Beer, S.F., 2014, 'Demythologising social cohesion: Towards a practical theological vision', Verbum et Ecclesia 35(2), Art. \#1344, 12 pages. http://dx.doi.org/10.4102/ ve.v35i2.1344

Donald, J. \& Ranttansi, A. (eds.), 1992, Race, culture and difference, Sage, London.

Dreyer, Y., 2008, 'A pastoral response to the unhealed wounds of gays exacerbated by indecision and in articulacy,' HTS 64(3), 1235-1254.

Elliott, W., 2003, Masculinity: Key South African issues and debates, A Soul City review, A companion review to 'Manhood: A gender in crises', http://fathers.co.za/ wp-content/uploads/2015/02/Masculinity-in-South-Africa.pdf

Fitzpatrick, S. \& Jones, A., 2005, 'Pursuing social justice or social cohesion? Coercion in street homelessness policies in England', Journal of Social Policy 34(3), 389-406. http://dx.doi.org/10.1017/S0047279405008834

Genever, S., 2016, "Wits students proclaim "f*** white people" - "It's not racist", SA Breaking News, 8 February 2016, viewed 16 March 2016, from http://www. sabreakingnews.co.za/2016/02/08/wits-students-proclaim-f-white-people-itsnot-racist/

Gennrich, D., 2013, Men and masculinities in South Africa, vol. 1: Stories of men making a difference, PACSA and Sonke Gender Justice Network, South Africa.

Gilligan, M., 2002, 'Diversity and accreditation: A measure of quality', Theological Education 38(2), 1-13.

Giroux, H.A., 2003, 'Pedagogies of difference, race, and representation: Film as a site of translation and politics', in P. Trifonas (ed.), Pedagogies of differenceRethinking education for social change, pp. 83-109, Routledge, New York.

Goduka, I.N., 1996, 'Challenges to traditionally white universities: Affirming diversity in the curriculum', South African Journal of Higher Education 10(1), 27-39.

Hames, M., 2011, 'Violence against black lesbians: Minding our language', Agenda 25(4), 87-91.

Harber, C.R. \& Serf, J., 2006, 'Teacher education for a democratic society in England and South Africa', Teaching and Teacher Education 22(8), 966-997.

Hay, P.L., 2014, Negotiating conviviality: The use of information and communication technologies by migrant members of the Bay Community Church in Cape Town Langaa Research and Publishing CIG, Mankon, Bamenda, Cameroon.

Jansen, J.D., 2009, Knowledge in the blood: Confronting race and the apartheid past, UCT Press, Cape Town.
James, W., 2012, 'The strange career of race classification in South Africa', posted on 4 December 2012, viewed 15 March 2016, from http://politicsweb.co.za/newsand-analysis/the-strange-career-of-race-classification-in-south

Jun, A. \& De la Rosa, M.L., 2013, 'Race, religion and responsibility in Christian higher education', Christian Higher Education 12, 1-4.

Lister, R., 2000, 'Strategies for social inclusion: Promoting social cohesion or socia justice?', in P. Askonas \& A. Steward (eds.), Social inclusion: Possibilities and tensions, pp. 37-54, Houndmills, Hampshire, Basingstoke; Palgrave Macmillan, New York.

Mbembe, A., 2013, 'Consumed by our lust for lost segregation', Mail and Guardian, 28 March 2013, viewed 16 March 2016, from http://mg.co.za/author/achillembembe

McNeil, J. \& Pozzi, C., 2007, 'Developing multicultural competency', in R. Priest \& A. Nieves (eds.), This side of heaven: Race, ethnicity and Christian faith, pp. 81-94, Oxford University Press, New York.

Nhlapo, T., 2016, "'F*** white people" is an appropriate expression of black pain', Daily Maverick, 9 February 2016, viewed 14 February 2016, from http://www. dailymaverick.co.za/opinionista/2016-02-09-f-white-people-is-an-appropriateexpression-of-black-pain/\#.VuuHef3bPIU

Pilane, P., 2016, 'Protest, politics and prayers at South Africa's universities', Mail and Guardian, 26 February 2016.

Punt, J., 2009, 'Post-apartheid racism in South Africa: The Bible, social identity and stereotyping', Religion and Theology 16, 246-272.

Quintal, G., 2016, 'Woman tells Malema he has no authority to talk about land, he isn't Khoisan,' viewed 13 February 2016, from http://www.timeslive.co.za/ politics/2016/02/13/Woman-tells-Malema-he-has-no-authority-to-talk-aboutland-he-isnt-Khoisan

Redpath, J., Morrell, R., Jewkes, R. \& Peacock, D., 2008, Masculinities and public policy in South Africa: Changing masculinities and working toward gender equality, Sonke Gender Justice Network, South Africa.

Rogan, M., 2014, 'Poverty may have declined, but women and female-headed households still suffer most', posted on 6 May 2014, http://www.econ3×3.org/ article/poverty-may-have-declined-women-and-female-headed-households-stillsuffer-most\#sthash.Spm6Z2CR.dpuf

Sadives, M., 2016, 'Number of complaints to HRC suggest South Africa is becoming more racist', Times Live, 11 January 2016, viewed 18 March 2016, from http:// www.timeslive.co.za/thetimes/2016/01/11/Number-of-complaints-to-HRCsuggest-South-Africa-is-becoming-more-racist

Schneider, C.G., 1997, 'From diversity to engaging difference: A framework for the higher education curriculum', in N. Cloete, J. Muller, M.W. Makgoba \& D. Ekong (eds.), Knowledge, identity and curriculum transformation in Africa, pp. 101-132, Longman, Cape Town.

Smith, D., 2009, Diversity's promise for higher education, Johns Hopkins University Press, Baltimore.

Smith, T.B., Stones, C.R., Peck, C.E. \& Naidoo, A.V., 2007, 'The association of racial attitudes and spiritual beliefs in post-apartheid South Africa', Mental Health, Religion and Culture 10(3), 263-274.

Sosin, C., 2014, Township life of LGBTIs: Dying for justice in Thokoza, Mail and Guardian, 23 May 2014, viewed 18 March 2016, from http://mg.co.za/ article/2014-05-22-township-life-of-Igbtis-dying-for-justice-in-thokoza

South African Reconciliation Barometer Survey: 2015 Report, Hofmeyr, J. \& Govender R., Cape Town: Institute for Justice and Reconciliation. http://www.ijr.org.za/ uploads/IJR_SARB_2015_WEB_002.pdf

Steyn, M. (ed.), 2011, Being different together: Case studies on diversity interventions in some South African organisations. Incudisa.wordpress.com.

Terreblanche, S., 2012, Lost in transformation: South Africa's search for a new future since 1986, Kmm Review Publishers.

Terreblanche, S., 2012b, 'Rich get richer through unfettered capitalism, not own devices', Mail and Guardian, 3 August 2012, http://mg.co.za/article/2012-08-0300-rich-get-richer-through-unfettered-capitalism-not-own-devices

Terreblanche, S., 2015, Personal interview with Prof. Sampie Terreblanche, 13 September 2015, Stellenbosch, South Africa.

Thislethwaite, S.B. \& Cairns, G.F. (eds.), 1994, Beyond theological tourism: Mentoring as a grassroots approach to theological education, Orbis Books, New York.

Van Rooi, L., 2010, 'Identity boundaries and the Eucharist: In search of the unity, catholicity and apostolicity of the church from the fringes of the Kalahari Desert' Deel 51(1\&2), 176-184.

Van Vollenhoven, W. \& Els, C.J., 2013, 'The human rights paradox of lesbian, gay, bisexual and transgender students in South African education', De Jure 46(1), 263-284.

Volf, M., 1996, Exclusion \& embrace: A theological exploration of identity, otherness, and reconciliation, Abingdon, Nashville, TN.

West, C., 1994, Race matters, Vintage Books, New York.

Wicks, J., 2016, 'Twitter erupts after KZN estate agent calls black people "monkeys"', Mail and Guardian, 04 January 2016, viewed 7 February 2016, from http://mg.co. za/article/2016-01-04-twitter-erupts-after-kzn-estate-agent-calls-black-peoplemonkeys

Woodley, R., 2001, Living in color: Embracing God's passion for ethnic diversity, Intervarsity Press, Downers Grove, IL. 